Note

\title{
Energy flow in castor bean (Ricinus communis L.) production systems
}

\author{
Adilson Nunes da Silva ${ }^{1}$; Thiago Libório Romanelli²; Klaus Reichardt ${ }^{3 *}$ \\ ${ }^{1}$ USP/ESALQ - Programa de Pós-Graduação em Fitotecnia, C.P. 09 - 13418-900 - Piracicaba, SP - Brasil. \\ ${ }^{2}$ USP/ESALQ - Depto. de Engenharia de Biossistemas, C.P. 09 - 13418-900 - Piracicaba, SP - Brasil. \\ ${ }^{3}$ USP/CENA - Lab. de Física do Solo, Av. Centenário, 303 - 13400-970 - Piracicaba, SP - Brasil. \\ *Corresponding author <klaus@cena.usp.br>
}

\begin{abstract}
Although energy analysis is a way to evaluate the sustainability of production systems, this practice is not often used in the agribusiness. In this context, the castor bean (Ricinus communis $\mathrm{L}$ ) is an agricultural crop not yet well studied despite its great potential in the Brazilian energetic scenario. This article aimed to evaluate the productive potential of the castor bean oil, using an energetic view applied to two management systems: low (System 1) and medium (System 2) technologies. The quantification of the used material fluxes was made converting these factors in energy units. The input energy fluxes were 3,170.6 MJ $\mathrm{ha}^{-1}$ and 10,366.0 MJ ha ${ }^{-1}$ for Systems 1 and 2, respectively. The energy balance of System 1 was 11,938.2 MJ $\mathrm{ha}^{-1}$ and that of System $216,296.5 \mathrm{MJ} \mathrm{ha}^{-1}$. The net energetic gain or the energy gain over the invested energy (EROI) of System 1 was 3.8 and of System 2, 2.6. Although presenting a greater energy demand and a lower EROI, System 2 had a greater energy balance, demonstrating a better viability of this cultivation system for the production of castor bean oil.

Key words: Energetic balance, oil crops, production technology, cultivation systems

\section{Fluxos de energia em sistemas de produção de mamona (Ricinus communis L.)}

\begin{abstract}
RESUMO: A análise energética é uma forma de se avaliar a sustentabilidade de um sistema produtivo, apesar de ainda pouco utilizada no setor agropecuário. Inserida neste setor encontra-se a produção da mamoneira (Ricinus communis L.), cultura ainda pouco estudada e que apresenta grande importância para o agronegócio brasileiro. Avaliou-se sob a ótica energética a produção potencial de óleo de mamona em dois sistemas de cultivo: com baixa (Sistema 1) e média (Sistema 2) tecnologias. Foi realizada a quantificação dos fluxos de materiais empregados nos dois sistemas de produção e conversão destes fatores em unidades de energia. Os fluxos de energia de entrada foram de $3.170,6 \mathrm{MJ} \mathrm{ha}^{-1}$ e $10.366 \mathrm{MJ} \mathrm{ha}^{-1}$ para os sistemas 1 e 2, respectivamente. O balanço de energia foi de 11.938,2 $\mathrm{MJ} \mathrm{ha}^{-1}$ no sistema 1 e 16.296,5 $\mathrm{MJ} \mathrm{ha}^{-1}$ no sistema 2. A lucratividade energética, retorno em energia sobre energia investida (EROI) do sistema 1 foi de 3,8 e no sistema 2 de 2,6. Apesar de apresentar uma maior demanda energética e menor EROI, o sistema 2 obteve maior balanço energético, demonstrando a maior viabilidade deste tipo de cultivo para a cultura da mamoneira.

Palavras-chave: Balanço energético, oleaginosas, tecnologia da produção, sistemas de cultivo
\end{abstract}

\section{Introduction}

As requirements for the agricultural sector to be environmentally suitable increase (Jacovine et al., 2009), it is necessary to adopt proper indicators and methodologies approaching sustainability (Esty and Chertow, 1997). One aspect for sustainability that must be taken into account in energy crops is the efficiency of being a viable source. The search for biofuel sources through agriculture has raised the question about land use for energy versus for food. So, biofuel sources shall present high efficiency on supplying energy in order to occupy less area and fulfill the demand (Freitas, 2004; Stoeglehner and Narodoslawsky, 2009; Yang et al, 2009; Khan et al., 2009)

Energy analyses determine the input and output energy flows which are used to calculate the net gain, the return over the invested energy and the energy embodied in a product or service (Chavanne and Frangi, 2008; Pimentel and Patzek, 2005; Pimentel et al., 2005). The considered energy input is not only the directly applied one (electricity, fuels), but also the energy embodied into the required goods (Wiedmann, 2009). Castor bean (Ricinus communis L.) is one of the energy crops with potential to provide raw material for biodiesel production. Although not making part anymore of the list of oil crops supported by the Brazilian government $\mathrm{Na}$ tional Plan for Biofuels, it may play an important role in the development of the national agricultural sector.

Brazil is the third largest producer of castor bean oil in the world $(113.1 \mathrm{Gg})$, behind India $(1053.0 \mathrm{Gg})$ and China (210.0 Gg) (FAO, 2007). Moreover, the Brazilian production has declined in the last decades, reaching a level which made Brazil to become an importer. This 
fact was a result of the little use of the available technology to the farmers, in general running enterprises of small or medium level and working under low competition (Savy Filho, 2005). Thus, this study aimed to evaluate the productive potential of the castor bean oil through the energy point of view, evaluating two cultivation systems: low and medium levels of technology adoption.

\section{Material and Methods}

The establishment of the energy balance was based on the methodology that has been applied to evaluate the development stage of agriculture since 1970, used by researchers like David Pimentel (Pimentel, 1980; Pimentel et al., 1983; Pimentel and Patzek, 2005; Pimentel et al., 2005), who analyzed energy fluxes and evaluated the sustainability degree of several crops. In the establishment of energy balances, one does not consider only the employed energy sources, as electricity and fuels, but also the energy spent by the manufacturing processes of other inputs, as well as by the labor used in the production process (Romanelli et al., 2008; Wiedmann, 2009).

Through the analysis of energy flows, one can establish the energy flows, identify the total demand and determinate the energy performance, which is reflected by the net gain and also by the ratio of energy made available over the invested energy. The indicators used to evaluate this performance are: energy balance (EB), EROI (energy return over investment) and energy intensity (EI). EB refers to the net energy gain per area while EROI refers to the ratio of energy made available by the required energy in a process and it can be understood as "energy profitability". EI is the embodied energy per unit of the obtained product. EI is an important indicator for products which have no energetic use (e.g.: fiber) and to be determined the energy input flow is related to the yield. These indicators are determined through the energy input (EIF) and output (EOF) flows. To determine EB (Eq. 1), the energy input flow (EIF) is subtracted from the output flow (EOF), resulting in the net gain per area.

Some authors refer to the energy balance as the ratio of energy made available and the energy required by a production system (Siqueira et al., 1999). However, in this study EROI (Eq. 2) was adopted (Hall, 2004).

$\mathrm{EB}=\mathrm{EOF}-\mathrm{EIF}$

$\mathrm{EROI}=(\mathrm{EOF}-\mathrm{EIF}) / \mathrm{EIF}$

In which $\mathrm{EB}, \mathrm{EIF}$, and $\mathrm{EOF}$ are given in $\mathrm{MJ} \mathrm{ha}{ }^{-1}$; and EROI in $\mathrm{MJ} \mathrm{MJ}^{-1}$.

The energy input flow is determined by multiplying the material flow and the energy embodied in the processes of obtaining them (Table 1). For the output energy flow (EOF), the potential oil in the grains was considered, since the activities necessary to extract oil out of the grains are not in the scope of the present study.

Considering the energy intensity of the harvested grains, the energy input flow can be related to the yield for the determination of EI (Eq. 3).

$\mathrm{EI}=\mathrm{EIF} / \mathrm{Y}$ $h a^{-1}$.

In which $\mathrm{EI}$ is given in $\mathrm{MJ} \mathrm{kg}^{-1}$; and the yield $\mathrm{Y}$ in $\mathrm{kg}$

Regarding material flows, there are two kinds of flows: the directly and the indirectly applied inputs. In this section, the steps for the material flow to be determined is shown as follows: i) Determination of the material flow of directly applied inputs; ii) Determination of the material flow of indirectly applied inputs. The latter includes: effective field capacity; fuel consumption; machinery depreciation; and labor.

The determination of the material flow was made according to the available data. Although there are other means to determine the operational capacity (ASAE,

Table 1 - Energy embodied in agricultural inputs.

\begin{tabular}{lccl}
\hline Input & Unit & Energy index & \multicolumn{1}{c}{ References } \\
\hline & & MJ unit & \\
Labor & $\mathrm{h}$ & 2.2 & Campos et al. (1998) \\
Diesel & $\mathrm{L}$ & 38.6 & Comitre (1993) \\
Machinery & $\mathrm{kg}$ & 68.9 & Ulbanere and Ferreira (1989) \\
Limestone & $\mathrm{kg}$ & 1.7 & Pellizzi (1992) \\
$\mathrm{N}$ & $\mathrm{kg}$ & 74.0 & Pellizzi (1992) \\
$\mathrm{P}_{2} \mathrm{O}_{5}$ & $\mathrm{~kg}$ & 12.6 & Pellizzi (1992) \\
$\mathrm{K}_{2} \mathrm{O}$ & $\mathrm{kg}$ & 6.7 & Pellizzi (1992) \\
Seeds & $\mathrm{kg}$ & 20.4 & Campos et al. (1998) \\
Other chemicals & $\mathrm{kg}$ & 184.7 & Pimentel (1980) \\
Fungicide & $\mathrm{L}$ & 97.1 & Pimentel (1980) \\
Herbicide & $\mathrm{L}$ & 454.2 & Fluck and Baird (1982) \\
Insecticide & $\mathrm{L}$ & 184.7 & Pimentel (1980) \\
\hline
\end{tabular}

Sci. Agric. (Piracicaba, Braz.), v.67, n.6, p.737-742, November/December 2010 
2003) it was determined by the inversion of the time spent per unit area by the mechanized operations to be performed (Eq. 4)

$\mathrm{OFc}=1 / \mathrm{t}$

where: $\mathrm{OFc}=$ Operational Field Capacity $\left(\mathrm{ha} \mathrm{h}^{-1}\right) ; \mathrm{t}=$ time spent for the mechanized operations $\left(\mathrm{h} \mathrm{ha}^{-1}\right)$.

Fuel consumption was determined by applying an index developed by Molin and Milan (2002) for the engine power of tractors and self-propelled machinery (Eq. 5).

$\mathrm{Fc}=(\mathrm{CI} * \mathrm{TP}) / \mathrm{OfC}$

where: $\mathrm{Fc}=$ Fuel consumption per area $\left(\mathrm{L} \mathrm{ha}^{-1}\right)$; $\mathrm{CI}=$ consumption index $\mathrm{CI}=0.163 \mathrm{~L}$. $\mathrm{kW}^{-1} \mathrm{~h}^{-1}$ (Molin and Milan, 2002); PT = tractor power (kW).

Machinery depreciation considered the machinery mass, its useful lifetime and the operational field capacity (Eq. 6). The concept of physical depreciation of a machine is based on the amount of metallic mass that will be required to build new machinery in order to replace it after its useful life. The material depreciation indicates the convergence of natural resources, e.g., iron ores and coal embodied in steel; oil embodied in tires etc.; these energies will indirectly be introduced into the production system.

$\mathrm{MD}=\mathrm{W} /(\mathrm{Ofc} \times \mathrm{UL})$

where: $\mathrm{MD}=$ machinery depreciation per unit area $(\mathrm{kg}$ $\left.\mathrm{ha}^{-1}\right) ; \mathrm{W}=$ machine mass $(\mathrm{kg}) ; \mathrm{UL}=$ the useful lifetime of the machinery (h).

Labor for manual operations, like driving or mixing pesticides in the sprayer tanks, was determined by the amount of labor considered in man-day (two men working half a day or one man working the whole day is a man-day) and the daily work journey (Eq. 7).

$\mathrm{Lb}=$ Man-day $\times \mathrm{LH}$

where: $\mathrm{Lb}=$ demanded human labor $\left(\mathrm{h} \mathrm{ha}^{-1}\right)$; Man-day $=$ the amount of work per operation $\left(\right.$ day $\left.\mathrm{ha}^{-1}\right) ; \mathrm{LH}=$ the labor hours per day ( $8 \mathrm{~h} \mathrm{day}^{-1}$ in this study).

Two distinct scenarios were evaluated: System 1, which presented low technology application, and System 2, with higher technology, mainly mechanization and intense use of agricultural inputs. The data of these production systems were obtained from FNP (2009). The oil content of the castor bean oscillates between 35 and $55 \%$, and its commercial standard is taken as $45 \%$ (Vieira et al., 1997). To quantify the potential oil yield it was considered that the castor bean has $45 \%$ oil content in the seed. For System 1 the grain productivity is $850 \mathrm{~kg}$ $\mathrm{ha}^{-1}$, which corresponds to $382.5 \mathrm{~kg} \mathrm{ha}^{-1}$ of oil. For System 2 the yield is $1,500 \mathrm{~kg} \mathrm{ha}^{-1}$, which corresponds to $675 \mathrm{~kg} \mathrm{ha}^{-1}$ of oil (FNP, 2009). Here the meaning of potential oil does not refer to extracted oil from the seeds, i.e., it represents the yield up to the moment of the processing and packaging of the harvested seeds. The energy content of oil and seed of the castor bean was 39.50 MJ kg ${ }^{-1}$.

\section{Results and Discussion}

System 1 presented a much lower energetic demand $\left(3,170.6 \mathrm{MJ} \mathrm{ha}^{-1}\right)$ in comparison to System 2 $(10,366.0 \mathrm{MJ}$ $\left.\mathrm{ha}^{-1}\right)$, as expected due to the lower intensity of its production process - less use of machinery, fuel and agricultural inputs (Table 2). Since mechanization was not fully applied, for System 1 the greatest share in the input energy flow was the fertilizer application with $60.8 \%$ of the total. The use 04-14-08 + B fertilizer was responsible for $33.1 \%$, while the ammonium sulphate for $27.7 \%$. The other directly applied inputs had meaningless participation ( $0.9 \%$ for seed and $0.1 \%$ for seed treatment). Labor had a considerable share $(9.8 \%)$ comparing to the current standards but it represents an acceptable value for less intensive production systems. The energy embodied in labor does not consider the social role for the maintenance of the rural workers in the countryside. Moreover, this is not the objective of this study, but one should highlight the importance that this role has and one suggests further studies on this respect which would surely enrich the discussions.

Due to the applied level of mechanization the largest share for energy demand in System 2 was fuel (diesel oil), with $54.6 \%$. Fertilizers were responsible for $23.7 \%$, being $15.2 \%$ for the $04-14-08+\mathrm{B}$ fertilizer and $8.5 \%$ for ammonium sulphate. Limestone, an input that was not used in System 1, was individually the second largest (16.1\%) input, corroborating for the increase of the energy demand in System 2.

Although machinery depreciation has increased from 155.0 to $340.8 \mathrm{MJ} \mathrm{ha}^{-1}$, its share decreased (System 2 compared to System 1) in 1.6\% (from 4.9 to 3.3\%) due to the higher increase of other kinds of inputs. Labor decreased from 9.8 to $1.8 \%$, due to its smaller input $\left(84.8 \mathrm{~h} \mathrm{ha}^{-1}\right.$ versus $\left.140.8 \mathrm{~h} \mathrm{ha}^{-1}\right)$. The intensification of the production system affected distinctly the indicators based on the energy flows (Table 3). The energy intensity, either regarding the harvested seeds or oil, was higher for System 2, as expected. The little difference in the observed increase for seed and oil (1.0\%) is due to the difference in oil content between these two scenarios. These data allow the comparison of the energy demand for obtaining castor bean oil with any other kind of oil.

Regarding the energy demand (input energy) there was a considerable difference $(+225 \%)$ between the two scenarios, which is due to both the low energy demand for System 1, which does not represent a largescale production system and the high energy intensity of System 2 through fuel consumption and fertilizer and limestone applications. The output energy (oil content) also presented an increase $(+76.5 \%)$, but in a lower rate than the demand, decreasing the energy profitability (EROI).

EROI was higher for System 1 (3.8 versus 1.6), indicating that despite its lower energy output, System 1 presented more efficiency regarding the energy invested by 
Table 2 - Energy flow of the castor bean production systems.

\begin{tabular}{|c|c|c|c|c|c|c|c|c|}
\hline \multirow{3}{*}{ 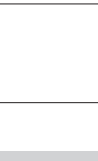 } & \multirow{2}{*}{ Materials } & \multirow{2}{*}{ Unit } & \multicolumn{2}{|c|}{ Material Flow } & \multicolumn{4}{|c|}{ Energy flow } \\
\hline & & & Syst. 1 & Syst. 2 & Syst. 1 & Syst. 2 & Syst. 1 & Syst. 2 \\
\hline & & & \multicolumn{2}{|c|}{ Unit ha ${ }^{-1}$} & \multicolumn{2}{|c|}{ MJ ha ${ }^{-1}$} & 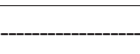 & 5 \\
\hline A & Machinery depr & $\mathrm{kg}$ & 2.25 & 4.95 & 155.0 & 340.8 & 4.9 & 3.3 \\
\hline A.1 & $1^{\text {st }}$ harrowing & $\mathrm{kg}$ & 1.48 & 0.43 & & & & \\
\hline A. 2 & $2^{\text {nd }}$ harrowing & $\mathrm{kg}$ & 0.43 & 0.24 & & & & \\
\hline A. 3 & Fertilizer appl. & $\mathrm{kg}$ & 0.24 & 0.60 & & & & \\
\hline A. 4 & Mowing & $\mathrm{kg}$ & 1.50 & 1.00 & & & & \\
\hline A. 5 & Fertilizer appl. & & & 0.30 & & & & \\
\hline A. 6 & Spraying & & & 0.90 & & & & \\
\hline A. 7 & Transport & & & 0.50 & & & & \\
\hline B & Labor & $\mathrm{h}$ & 140.80 & & 309.8 & 186.6 & 9.8 & 1.8 \\
\hline B.1 & Seed treatment & $\mathrm{h}$ & 0.8 & 0.8 & & & & \\
\hline B. 2 & Sowing & $\mathrm{h}$ & 8.0 & - & & & & \\
\hline B. 3 & Manual weeding & $\mathrm{h}$ & 2.0 & - & & & & \\
\hline B. 4 & Fertilizer appl. & $\mathrm{h}$ & 8.0 & - & & & & \\
\hline B.5 & Spraying & $\mathrm{h}$ & 4.0 & - & & & & \\
\hline B.6 & Harvesting & $\mathrm{h}$ & 56.0 & 56.0 & & & & \\
\hline B.7 & Drying & $\mathrm{h}$ & 24.0 & 24.0 & & & & \\
\hline B. 8 & Transport & $\mathrm{h}$ & 12.0 & - & & & & \\
\hline B. 9 & Packing & $\mathrm{h}$ & 4.0 & 4.0 & & & & \\
\hline \multirow[t]{2}{*}{$\mathrm{C}$} & Agric. inputs & & & & & & & \\
\hline & Limestone & $\mathrm{kg}$ & - & 1000.0 & - & 1670.0 & & 16.1 \\
\hline C. 2 & $04-14-08+B$ & $\mathrm{~kg}$ & 200.0 & 300.0 & 1049.2 & 1573.8 & 33.1 & 15.2 \\
\hline C. 3 & $\left(\mathrm{NH}_{3}\right)_{2} \mathrm{SO}_{4}$ & $\mathrm{~kg}$ & 40.0 & 40.0 & 879.2 & 879.2 & 27.7 & 8.5 \\
\hline C. 4 & Insecticide & $\mathrm{L}$ & 0.02 & 0.03 & 2.3 & 3.5 & 0.1 & 0.0 \\
\hline C.5 & Seed & $\mathrm{kg}$ & 5.0 & 10.0 & 28.5 & 56.9 & 0.9 & 0.5 \\
\hline C. 6 & Fuel & $\mathrm{L}$ & 19.4 & 146.5 & 746.9 & 5655.3 & 23.6 & 54.6 \\
\hline Total & & & & & 3170.6 & 10366.0 & 100.0 & 100.0 \\
\hline
\end{tabular}

*implement attached to a 55.2-kW tractor.

Table 3 - Energy flow and indicators of castor bean production systems.

\begin{tabular}{|c|c|c|c|c|c|c|}
\hline \multirow{2}{*}{ Indicators } & \multicolumn{2}{|c|}{ Energy Intensity } & \multicolumn{2}{|c|}{ Energy } & \multirow{2}{*}{ EB } & \multirow{2}{*}{ EROI } \\
\hline & Seed & Oil & Input & Output & & \\
\hline Unit & \multicolumn{2}{|c|}{$\mathrm{MJ} \mathrm{kg}^{-1}$} & \multicolumn{3}{|c|}{ GJ ha ${ }^{-1}$} & $\mathrm{MJ} \mathrm{MJ}^{-1}$ \\
\hline System 1 & 3.7 & 8.3 & 3.2 & 15.1 & 11.9 & 3.8 \\
\hline System 2 & 6.9 & 15.4 & 10.4 & 26.7 & 16.3 & 1.6 \\
\hline$\Delta(\%)$ & +86.5 & +85.5 & +225.0 & +76.5 & +36.5 & -57.9 \\
\hline
\end{tabular}

the production systems. On the other hand, the energy balance improved by the intensification of the production system $(+36.5 \%)$, presenting higher efficiency of the land occupation, since more net energy was obtained per unit area. There is not a better indicator between energy balance and EROI. Both shall be used and, depending upon the circumstances of the scenarios, one or another is going to have more significance. For instance, if there are no constraints on resources, such as land availability, the best EROI will indicate better options. But, if the option with the highest EROI does not supply the required energy demand society will need less efficient energy sources but with more net energy being supplied. For instance, wind energy is more efficient (higher EROI) than thermoelectric plants burning coal, but it will not provide enough energy for most enterprises. 
Thus, for the decision-making to be done, one should know the next larger scale in which the energy source is located. For instance, if there was a demand for 1000 GJ, System 1 would need 66.2 ha to provide it, while System 2 would need 37.5 ha. The latter demands less area, but it depends on more non-renewable sources, such as limestone, machinery, fuel, fertilizer, so that it increases the environmental pressures and external dependencies of the production process.

The EROIs of both production systems show that this crop is not very efficient as an energy source because it should be processed to produce biodiesel, which would involve transport, industrial processes, chemicals, labor and more energy would be demanded. So, biodiesel for castor oil could be an energy drain instead of a source, mainly from oil produced by System 2. But, castor oil can be used as a biodiesel source in areas where there is no infrastructure for fuel to be transported to, such as some parts of north and northeast regions of Brazil, because it would improve the living conditions (electricity from generators) without posing environmental pressure into the next larger scale, such as road building (which increases deforestation) or fuel transportation (carbon emission and higher costs). This is not a discussion based in the presented data, but an idea for further studies.

Other oil sources than castor beans, whose oil is toxic to humans, will play an important role not only as components of the population food diet, whose demand is increasing nowadays, but also as an energy source for the energetic matrix of this century, in a friendly way in relation to environmental protection (Savy Filho, 2005). Since the castor bean does not anymore take part of the Brazilian biofuel program and that its main use will not be directed to the production of energy, this study provides basis for the energy evaluation for other crops, regardless of the participation on the governmental agenda.

\section{Conclusions}

The methodology here applied is appropriate to evaluate bioenergy sources. The use of low technology in the production resulted in a lower energy demand, a lower energy balance and a higher EROI. On the other hand, the use of medium technology resulted in a higher energy demand, a lower EROI and higher energy balance. The first is better if the energy demand can be fulfilled and the latter occupies land more efficiently from the energy point of view. The best option can be only stated if there is information about supply and demand, dependence upon external resources and land availability. Although castor bean is out of the Brazilian energy plan, it may be useful in remote areas, where it may be used as biodiesel source.

\section{Acknowledgement}

To CNPq and FAPESP for the granted fellowships.

\section{References}

American Society of Agricultural Engineers [ASAE]. 2003. D497.4 Agricultural Machinery Management Data. p. 373380. In: ASAE. ASAE Standards 2003. ASAE, St. Joseph, MI, USA.

Brazilian Institute of Geography and Statistics [IBGE]. 2007. Agricultural production in the federative states. IBGE. Available a t : h t t p:// w w w . ibge.gov.br/estados a t / temas.php? sigla $=$ ba\&tema $=$ pamclo2007 [Accessed Jul. 05, 2009]. (in Portuguese).

Campos, A.T.; Ferreira, W.A.; Yamaguchi, L.C.T.; Resende, H.; Almeida, F.M. 1998. Economic and energy balances of maize silage for dairy cattle. Engenharia Rural 9: 1-20. (in Portuguese with abstract in English).

Chavanne, X.; Frangi, J.P. 2008. Energy yield for the production of ethanol from corn. Comptes Rendus Geoscience 340: 263-287. (in French, with abstract in English).

Comitre, V. 1993. The question of energy and the technological standard of Brazilian agriculture. Informações Econômicas 12: 29-35. (in Portuguese, with abstract in English).

Esty, D.C.; Chertow, M. 1997. Thinking ecologically: an introduction. p. 1-14. In: Chertow, M.; Esty, D.C., eds. Thinking ecologically: building the next generation of environmental policy. Yale University Press, New Haven, CT, USA.

FAO Statistics. 2007. Production and trade - Castor beans. FAO. Available at: http://faostat.fao.org [Accessed Jul. 05, 2009].

Freitas, D.G.F.; Khan, A.S.; Silva, L.M.R. 2004. Technological level and production profit of bee honey (Apis mellifera) in Ceará. Revista de Economia e Sociologia Rural 42: 171-188. (in Portuguese, with abstract in English).

FNP. 2009. Agrianual 2009: Annual of Brazilian Agriculture. FNP Consultoria \& Comércio. São Paulo, SP, Brazil. (in Portuguese).

Fluck, R.C.; Baird, C.D. 1982. Agricultural energetics. UF/IFAS Press, Gainesville, FL, USA.

Hall, C.A.S. 2004. The myth of sustainable development: personal reflection on energy, its relation to neoclassical economics and Stanley Jevons. Journal of Energy Resource Technology 126: 85-89.

Jacovine, L.A.G.; Viana, W.D.; Alves, R.R.; Walter, M.K.C.; Silva, M.L.; Valverde, S.R. 2009. Environmental approach of companies within the pulp/paper, metalurgical and sugar/ alcohol sectors. Scientia Agricola 66: 1-7.

Khan, A.S.; Matos, V.D.; Lima, P.S. 2009. Performance of apiculture in the Ceará State: competitivity, technological level and constraint factors. Revista de Economia e Sociologia Rural 47: 651-675. (in Portuguese, with abstract in English).

Molin, J.P.; Milan, M. 2002. Tractor-implements: designing, operational capacity and cost p. 409-436. In: Gonçalves, J.L.M; Stape, J.L. Soil conservation and cultivation for planted forests. IPEF, Piracicaba, SP, Brazil. (in Portuguese).

Pellizzi, G. 1992. Use of energy and labour in Italian agriculture. Journal of Agricultural Engineering Research 52: 111-119.

Pimentel, D. 1980. Handbook of energy utilization in agriculture. CRC Press, Boca Ratón, FL, USA.

Pimentel, D.; Berardi, G.; Fast, S. 1983. Energy efficiency of farming systems: organic and conventional agriculture. Agriculture, Ecosystems and Environment 9: 359-372.

Pimentel, D; Patzek, T.W. 2005. Ethanol production using corn, switchgrass, and wood: biodiesel production using soybean and sunflower. Natural Resources Research 14: 65-76.

Pimentel, D.; Hepperly, P.; Hanson, J.; Douds, D.; Seidel; R. 2005. Environmental, energetic and economic comparisons of organic and conventional farming systems. BioScience 55: 573-582.

Romanelli, T.L., Cohen, M.J., Milan, M.; Brown, M.T. 2008. Emergy synthesis of intensive eucalyptus cultivation in São Paulo, Brazil. Forest Science 54: 228-241. 
Savy Filho, A. 2005. Agricultural Technology for the Castor Bean Crop. EMOPI. Campinas, SP, Brazil. (in Portuguese).

Siqueira, R.; Gamero, C.A.; Boller, W. 1999. Energy balance in planting and managing crops for soil coverage. Engenharia Agrícola 19:80-89. (in Portuguese with abstract in English).

Stoeglehner, G.; Narodoslawsky, M. 2009. How sustainable are biofuels? Answers and further questions arising from an ecological footprint perspective. Bioresource Technology 100: 3825-3830.

Ulbanere, R.C.; Ferreira, W.A. 1989. Energy balance in corn production in the São Paulo State, Brazil. Engenharia Agrícola 4: 35-42. (in Portuguese, with abstract in English).

Yang, H.; Zhou, Y.; LIU, J. 2009. Land and water requirements of biofuel and implications for food supply and the environment in China. Energy Policy 37: 1876-1885.
Wiedmann, T. 2009. A first empirical comparison of energy footprints embodied in trade: MRIO versus PLUM. Ecological Economics 68: 1975-1990.

Vieira, R.M.; Lima, E.F.; Batista, F.A.S. 1997. p.139-150. Diagnosis and perspectives for the castor bean crop in Brazil. In: CNPA/ MAA/ABIOVE, eds. Technical Meeting on Oleaginous Raw Material in Brazil. Embrapa-CNPA/MAA/ABIOVE, Campina Grande, PB, Brazil. (in Portuguese).

Received September 30, 2009

Accepted June 22, 2010 